World Lumen Congress 2021 | May 26-30, 2021 |

Iasi, Romania

\title{
Public Support for the EU in Times of Crisis and the Drivers of Euroscepticism
}

\author{
Iuliana-Lăcrămioara TINCU
}

https://doi.org/10.18662/wlc2021/66

How to cite: Tincu, I-L. (2021). The Evaluation of Distance Learning in Tourism Education in the Pandemic Process. In A. Sandu (vol. ed.), Lumen Proceedings: Vol. 17 World Lumen Congress 2021 (pp. 662-665). Iasi, Romania: LUMEN Publishing House. https://doi.org/10.18662/wlc2021/66 


\title{
Public Support for the EU in Times of Crisis and the Drivers of Euroscepticism
}

\author{
Iuliana-Lăcrămioara TINCU1
}

\begin{abstract}
In the context of the economic, political and social crises that unfolded during the recent years, the European Union had to withstand a growing pressure from the part of its dissatisfied citizens. The long-term effects of the economic crisis, the limited ability to manage refugee flows or the difficulty to come up with joint solutions to pressing issues have highlighted the shortcoming of the EU as a political system, while also giving rise to growing criticism from EU citizens and the loss of their trust. The present article embraces a theoretical standpoint and aims to offer some initial insights into the potential connections between recent crises and the evolution of European citizens' attitudes in relation to the EU by exploring the existing literature on the topic. This perspective could further open new paths in analysing the roots and drivers of Euroscepticism by advancing the question on whether crises can impact the attitudes of EU citizens on the overall integration process.
\end{abstract}

Keywords: European Union, public opinion, Euroscepticism, EU citizenship, crisis salience.

\section{Introduction}

The EU and its unity have been repeatedly put under stress by a multitude of crises, whether talking about the euro crisis, the migrant crisis, numerous security crises or the recent sanitary crisis. As a system that relies on democratic principles and on the support of its citizens, it is interesting to analyse whether these critical times and the (in)ability of the EU to come up with satisfactory solutions in the management of the crises had any perceivable impact on the overall attitude of the citizens towards the integration project. This paper tries to explore, by analysing relevant literature on the topic, the potential impact of crises, understood as rarely occurring events that can destabilise both the existing order and citizens' longstanding beliefs (Habermas, 1975), on the public attitudes and support of EU citizens for the European integration project. Finally, the paper also addresses Brexit as a potential consequence of the unsuccessful attempts to address the fears and needs of EU citizens on the long-term.

The European project has evolved from an elite-driven process that is known as an era of "permissive consensus", where people had a passive role in the integration process towards the current "constraining dissensus" that is

\footnotetext{
${ }^{1} \mathrm{PhD}$ candidate, “Alexandru Ioan Cuza University”, Iaşi, Romania. iuliana.tatarau@gmail.com
} 
characterised by more contestation and, overall, more power to the people (Hooghe \& Marks, 2009). In an attempt to explain how EU citizens shifted from a general indifference to the lack of democratic accountability of the EU to a sudden awakening, Scharpf introduces the concept of "legitimacy intermediation" (Scharpf, 2015). By referring to the euro crisis, he explains that, while before the crisis European policies had low political salience (Scharpf, 2015, p. 137), the euro crisis and its dire implications, along with the strong intervention of European actors produced a drastic change of perspectives. All of a sudden, the power of European institutions was no longer intermediated by national authorities.

On a similar note, Innerarity (2018, pp. 188-190) argues that the EU represents an attempt to impose a narrative that is uncommon for the peoples of Europe that strongly relate to the principles of the nation state and are still tied with strong national loyalties. Thus, the EU tries to reconcile national particularisms and to conceive the idea of a new type of solidarity and a new type of polity that would ultimately lead to advantages that the states could not provide individually. However, the crises that shaped the EU, show that the idea of "us" and its new pact of confidence it proposes remains weak.

\section{European integration in three defining moments. Shaping the EU narrative}

Generally, voters tend to blame their governments and elected representatives during times of economic, social or political unrest. This was also true during the economic crisis, as citizens blamed their incumbent governments for the economic downturn that impacted their personal lives (Hobolt, 2015, pp. 4849). However, the 2008 crisis was different from previous economic crises, as European citizens identified a new level of governance that shared the blame for the unfavourable economic conditions. The financial and economic crisis impacted the public salience of EU decisions and their redistributive consequences especially in the Eurozone, with EU citizens and commentators shifting their attention from a state-centric perspective to the design flaws of the Economic and Monetary Union and the lack of a common direction for EU leaders (Hobolt, 2015, p. 48).

The euro crisis had implications on the overall citizen perception of the EU and on its legitimacy. Between September 2007 and the end of 2012, Eurobarometer data has shown a dramatic decrease in trust in the EU, the indicator plummeting from 57\% to a historic low of 33\% (Scharpf, 2015, p. 137). Moreover, in 2012, 83\% Greeks, 47\% Spaniards, and 39\% Italians considered that other countries of the EU constitute a major threat to their own national economies (Hobolt, 2015, p. 48-49.

The handling of the 2015 refugee crisis represented a second turning point for the European project that raised fundamental questions on the stability of the EU foundations. The divergent approach of Member States in tackling the crisis showed the limits of free movement within the EU and amplified the self-interest of nationstates. In the year of 2015, more than 1 million people sought refuge in the countries 
of the EU, with the majority of them mainly concentrated in the states in Northern Europe (Harteveld et al., 2017, p. 157). The questioning of EU's authority by the Member States on the resettlement of refugees also highlighted the feeble foundations of supranational governance and the objections raised especially by the Member States in Eastern Europe to the system of mandatory quotas showed the limits of European solidarity (Stockemer et al., 2020, pp. 886-887).

The 2015 refugee crisis managed to fuel discontent among Europeans and to highlight the still major weight of national identities, as well as the shortcoming of community. As it was also the case of the 2008 economic crisis, the events of 2015 were highly politicised and mediatised, which led to increased levels of salience of the topic among European citizens. It is believed that the crisis was responsible for a decrease in public support for the EU, as well as a polarisation of EU attitudes that prompted a new impetus for a populist discourse and an anti-immigration and anti-European agenda in European elections.

Finally, the UK withdrawal from the EU following the results of the 2016 British referendum can be seen as an indicator of the lack of trust among the EU nations and citizens alike, as well as towards the EU project. However, UK's particular status within EU must be remembered at all times, as the perception of its EU membership has been marked by a general discontent and polarised opinions (Hobolt, 2016, p. 1260). In the period prior to the 2016 referendum, the British electorate was clearly divided on the remain versus leave axis, with a strong mediatisation and political campaign that influenced the decision of the public (Hobolt, 2016, p. 1263). Brexit has highlighted the consequences of the gap between the winners and losers of European integration and of a globalised approach (Hobolt, 2016, p. 1273). While, for the moment, it does not seem that the decision of the UK to leave the EU has carried over any spill over effects, it has definitely showed the reversible character of European integration. The implications of Brexit for the EU also include a warning signal, showing that the failure to address the needs of those left behind, as well as the fears and discontent of people when it comes to sensitive issues such as immigration, prosperity or even cultural aspects could potentially lead to drastic punitive actions.

\section{Conclusions: crises and public support - what can be learnt?}

Protests in the wake of the economic crisis and the toll it inflicted on EU citizens' trust, the opposition towards refugees and the UK decision to leave the EU could be perceived as indicators of an endemic distrust among the participants in the European integration project and of the levels of destabilisation that crises can bring in terms of public support for the European Union. As the EU became increasingly politicised and the EU citizens more and more aware and scrutinising towards decisions at EU level, the EU must prove, more than ever, that the alternative political system that it proposes is, indeed, capable of producing increased benefits and defending the "common European good" in a manner that is not attainable at national level. 
The events that have been addressed in this paper can be considered as systemic crises that challenged the foundations of the EU project and brought to centre stage new issues and difficulties that the supranational level of governance must tackle in order to ensure its future sustainability. In other words, it could be argued that a linkage between crises and the perception of citizens on the EU as a political system, as well as on the integration process, can be identified and it could be further explored in an attempt to analyse new avenues in considering Euroscepticism. The real consequences of Brexit or the toll of the current sanitary crisis are yet to be fully understood and are likely to also influence the way forward for the European integration project in accordance to EU's ability to reshape itself according to the needs and concerns raised by the public.

\section{References}

Habermas, J. (1975). Legitimation crisis. Beacon Press.

Harteveld, E., Schaper, J., Lange, S., \& van der Brug, W. (2017). Blaming Brussels? The Impact of (News about) the Refugee Crisis on Attitudes towards the EU and National Politics. JCMS, 56(1), 157-177. https://doi.org/10.1111/jcms.12664

Hobolt, S. B. (2015). Public Attitudes towards the Euro Crisis. In S. B. Hobolt \& O. Cramme (Eds.), Democratic Politics in a European Union Under Stress (pp. 1-19). Oxford University Press.

Hobolt, S. (2016). The Brexit vote: a divided nation, a divided continent. Journal of European Public Policy, 23(9), 1259-1277. https://doi.org/10.1080/13501763.2016.1225785

Hooghe, L., \& Marks, G. (2009). A postfunctionalist theory of European integration: From permissive consensus to constraining dissensus. British Journal of Political Science, 39(1), 1-23. https://doi.org/10.1017/S0007123408000409

Innerarity, D. (2018). Democracy in Europe. A Political Philosophy of the EU. Palgrave Macmillan.

Scharpf, F. W. (2015). No exit from the euro-rescuing trap? In V. Schneider \& B. Eberlein (Eds.), Complex democracy: V arieties, crises, and transformations (pp. 135-165). Springer.

Stockemer, D., Niemann, A., Unger, D., \& Speyer, J. (2020). The "Refugee Crisis," Immigration Attitudes, and Euroscepticism. International Migration Review, 54(3), 883-912. https://doi.org/10.1177\%2F0197918319879926 